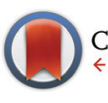

CrossMark \&lick for updates

Cite this: Dalton Trans., 2016, 45 8367

Received 31st March 2016, Accepted 11th April 2016

DOI: 10.1039/c6dt01242f

www.rsc.org/dalton

\title{
The contrasting catalytic efficiency and cancer cell antiproliferative activity of stereoselective organoruthenium transfer hydrogenation catalysts $\uparrow$
}

\author{
Ying Fu, $\$ \S^{a}$ Carlos Sanchez-Cano, $\ddagger^{a}$ Rina Soni, $t^{a}$ Isolda Romero-Canelon, ${ }^{a}$

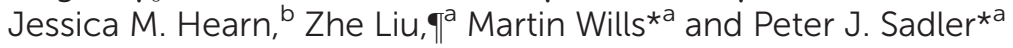

\begin{abstract}
The rapidly growing area of catalytic ruthenium chemistry has provided new complexes with potential as organometallic anticancer agents with novel mechanisms of action. Here we report the anticancer activity of four neutral organometallic Ru" arene $\mathrm{N}$-tosyl-1,2-diphenylethane-1,2-diamine (TSDPEN) tethered transfer hydrogenation catalysts. The enantiomers $(R, R)-\left[R u\left(\eta^{6}-\mathrm{C}_{6} \mathrm{H}_{5}\left(\mathrm{CH}_{2}\right)_{3}-\mathrm{TsDPEN}-\mathrm{N}-\mathrm{Me}\right) \mathrm{Cl}\right](\mathbf{8})$ and $(\mathrm{S}, \mathrm{S})-\left[\mathrm{Ru}\left(\eta^{6}-\mathrm{C}_{6} \mathrm{H}_{5}\left(\mathrm{CH}_{2}\right)_{3}-\mathrm{Ts} D P E N-\mathrm{N}-\mathrm{Me}\right) \mathrm{Cl}\right](\mathbf{8 a})$ exhibited higher potency than cisplatin against A2780 human ovarian cancer cells. When the $\mathrm{N}$-methyl was replaced by $\mathrm{N}-\mathrm{H}$, i.e. to give $(R, R)-\left[\mathrm{Ru}\left(\eta^{6}-\mathrm{Ph}\left(\mathrm{CH}_{2}\right)_{3}{ }^{-}\right.\right.$ TsDPEN-NH)Cl] (7) and $(S, S)-\left[R u\left(\eta^{6}-\mathrm{Ph}\left(\mathrm{CH}_{2}\right)_{3}-\mathrm{TsDPEN}-\mathrm{NH}\right) \mathrm{Cl}\right]$ (7a), respectively, anticancer activity decreased $>5$-fold. Their antiproliferative activity appears to be linked to their ability to accumulate in cells, and their mechanism of action might involve inhibition of tubulin polymerisation. This appears to be the first report of the potent anticancer activity of tethered $\mathrm{Ru}^{\mathrm{Il}}$ arene complexes, and the structureactivity relationship suggests that the $\mathrm{N}$-methyl substituents are important for potency. In the National Cancer Institute $\mathbf{6 0 - c a n c e r - c e l l - l i n e ~ s c r e e n , ~ c o m p l e x e s ~} \mathbf{8}$ and $\mathbf{8 a}$ exhibited higher activity than cisplatin towards a broad range of cancer cell lines. Intriguingly, in contrast to their potent anticancer properties, complexes $\mathbf{8 / 8}$ a are poor catalysts for asymmetric transfer hydrogenation, whereas complexes $7 / 7 \mathbf{a}$ are effective asymmetric hydrogenation catalysts.
\end{abstract}

\section{Introduction}

Platinum-group metal complexes, including those of $\mathrm{Ru},{ }^{1,2}$ $\mathrm{Rh},{ }^{3,4} \mathrm{Pd},{ }^{5,6} \mathrm{Ir},{ }^{7-10} \mathrm{Os},{ }^{11-13}$ and $\mathrm{Pt},{ }^{14-18}$ have shown potent anticancer activity in vitro and in vivo. Among them, the anticancer activity of organometallic half-sandwich $\mathrm{Ru}^{\mathrm{II}}$ complexes has been well studied recently. ${ }^{19-27}$ Although these $\mathrm{Ru}^{\mathrm{II}}$ complexes share a similar general half-sandwich structure, ${ }^{28-30}$ their mechanisms of action vary, ${ }^{27,31-33}$ as illustrated by the following examples. (1) Complex DW1 (Scheme 1, compound 1), developed by Meggers et al., is a potent inhibitor of glycogen synthase kinase (GSK-3 $\beta$ ); and induces apoptosis of cancer

\footnotetext{
${ }^{a}$ Department of Chemistry, University of Warwick, Gibbet Hill Road, Coventry, CV4 7AL, UK. E-mail:p.j.sadler@warwick.ac.uk

${ }^{b}$ Warwick Systems Biology Centre, University of Warwick, Gibbet Hill Road, Coventry, CV4 $7 A L, U K$

$\dagger$ Electronic supplementary information (ESI) available. See DOI: 10.1039/ c6dt01242f

$\$$ These authors contributed equally to this work.

$\S$ Current address: Laboratory of Molecular Biology, Center for Cancer Research, NCI, Building 37, Room 5011, Bethesda, MD 20892-4264.

ๆ Current address: Qufu Normal University, China.
}

cells through a p53 dependent pathway. ${ }^{34}(2)\left[\mathrm{Ru}\left(\eta^{6}\right.\right.$-biphenyl) (ethylenediamine) $] \mathrm{PF}_{6}$ (Scheme 1, compound 2) is believed to target DNA; the labile $\mathrm{Ru}-\mathrm{Cl}$ bond can undergo hydrolysis to form $\mathrm{Ru}-\mathrm{OH}_{2}$ intracellularly, whereas this hydrolysis is suppressed extracellularly. ${ }^{35}$ The hydrolysis step generates a reactive site on the Ru centre which can bind to DNA bases (e.g. guanine) and lead to DNA double-strand breaks and apoptosis. (3) $\left[\mathrm{Ru}\left(\eta^{6}\right.\right.$-arene $) \mathrm{Cl}_{2}$ (pta) $]\{$ PTA = 1,3,5-triaza-7-phosphatricyclo[3.3.1.1]decane\} (Scheme 1, compound 3) exhibits promising anti-metastatic effects in vitro and in vivo. ${ }^{36,37}$ (4) Ruthenium arene paullone complexes, e.g. $\left(\eta^{6}-p\right.$-cymene $)\{9-$ bromo-6$[(\alpha-$ picolyl- $\kappa N)$ imino- $k N]-7,12$-dihydroindolo[3,2- $d][1]$ benzazepine $\}$ chlororuthenium(II) chloride (Scheme 1, compound 4) are putative cyclin-dependent kinase (CDK) inhibitors, showing potent anticancer activity in vitro. ${ }^{38}(5)\left[\mathrm{Ru}\left(\eta^{6}\right.\right.$-arene)(TsEn)Cl] (Scheme 1, compound 5 ) is able to target cancer cells by altering the NADH/NAD ${ }^{+}$ratio in cells. ${ }^{27}$ There is much current interest in exploring alternative profiles of reactivity for ruthenium arene complexes. Progress in optimising activity has centred on modifying the arene ${ }^{39,40}$ the monodentate ligand, ${ }^{41-43}$ or chelating ligand $;^{4-51}$ and multinuclear ruthenium arene complexes can also exhibit potent anticancer activity. ${ }^{52-54}$ 


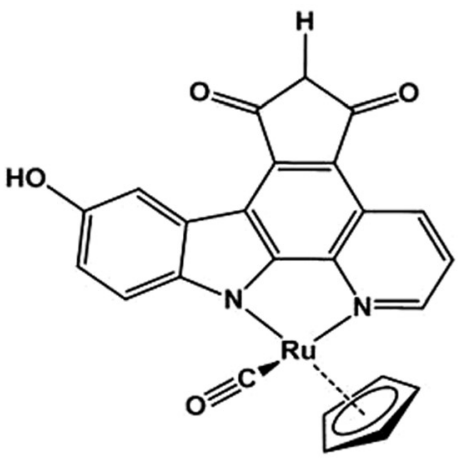

1

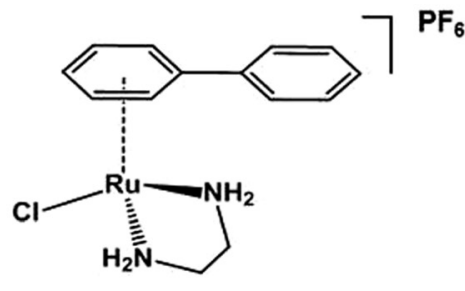

2

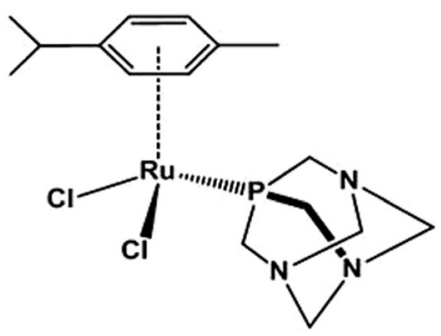

3
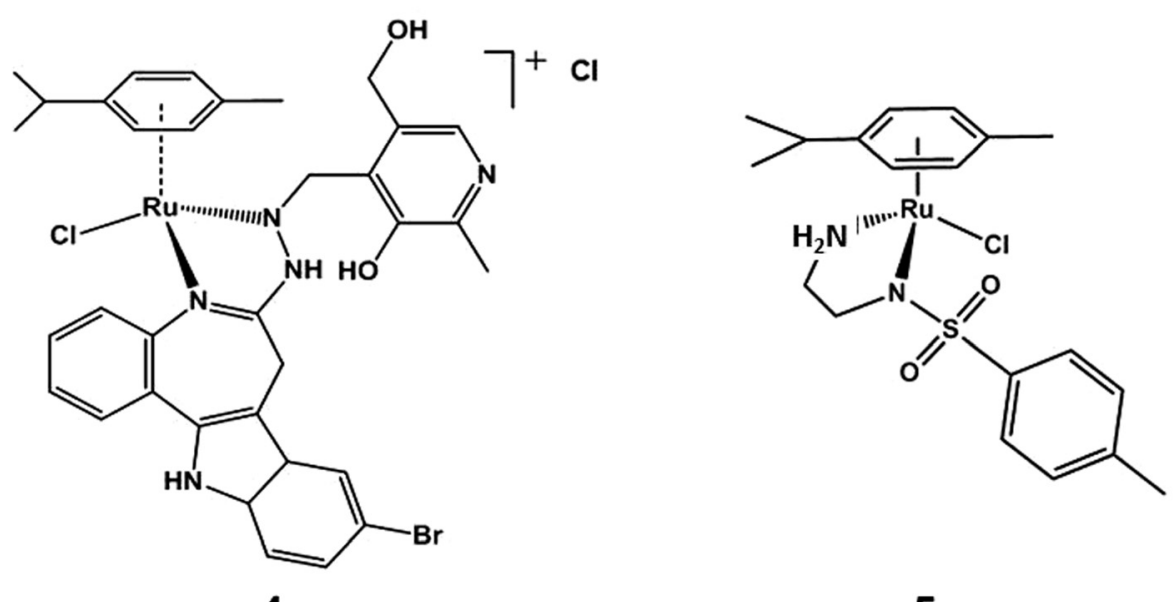

4

5

Scheme 1 Examples of organometallic half-sandwich Rull complexes which exhibit anticancer activity. 1. DW1 (the $R$ enantiomer of the DW $1 / 2$ racemic mixture); 2. [Ru( $\eta^{6}$-biphenyl)(ethylenediamine)]PF 6 ; 3 . $\left[\mathrm{Ru}\left(\eta^{6}-p\right.\right.$-cymene) $\mathrm{Cl}_{2}$ (pta)] (PTA = 1,3,5-triaza-7-phosphatricyclo-[3.3.1.1]decane); 4. $\left(\eta^{6}-p\right.$-cymene $)\{9$-bromo-6-[( $\alpha$-picolyl- $\kappa N)$ imino- $\left.\kappa N\right]-7,12$-dihydroindolo[3,2- $\left.d\right][1]$ benzazepine $\}$ chlororuthenium( $(I)$ chloride; 5. $\left[R u\left(\eta^{6}-p\right.\right.$-cymene) (TsEn)Cl] (TsEn = $p$-methybenzene).

Organometallic half-sandwich $\mathrm{Ru}^{\mathrm{II}}$ complexes have also been shown to be outstanding catalysts for asymmetric transfer hydrogenation of ketones and imines. Noyori and coworkers ${ }^{55,56}$ first reported the synthesis and use of compound $N$-[(1R,2R)-1,2-diphenylethyl]-4-methylbenzenesulfonamide ( $p$-cymene)ruthenium chloride 6 (Scheme 2) as a catalyst for the asymmetric hydrogenation of ketones and imines giving products in high enantiomeric excesses, using a number of reducing agents including hydrogen gas, isopropanol/base, and formic acid/triethylamine (FA/TEA). ${ }^{57,58}$ Some $\mathrm{Ru}^{\mathrm{II}}$ arene complexes are active both as hydrogenation catalysts and as anticancer agents. ${ }^{27,59,60}$

There are four major connections between reported organometallic half-sandwich $\mathrm{Ru}^{\mathrm{II}}$ complexes in the apparently distinct fields of anticancer activity and catalysis. (i) Structural similarity: they have the general structure $\left[\mathrm{Ru}\left(\eta^{6}\right.\right.$-arene)(YZ) $(\mathrm{X})$ ], where $\mathrm{YZ}$ is typically a chelating diamine ligand (e.g. ethylenediamine, $N$-tosylethylenediamine ${ }^{61}$ and $\mathrm{X}$ is a halide (e.g. $\mathrm{Cl}){ }^{62}$ (ii) the monodentate ligand, which has a similar function in both cases, is normally a leaving group for hydride formation or coordination of biomolecules to the $\mathrm{Ru}^{\mathrm{II}}$ centre, for the catalytic and anticancer effects, respectively; ${ }^{63-65}$ (iii) the chelating ligand, which often plays an important role in the selectivity of anticancer targets $^{1}$ and regioselectivity in catalysis; ${ }^{66-68}$ (iv) chirality, which is important for both of the two families of complexes, plays a vital role in substrate and target recognition. ${ }^{69-71}$

'Tethered' complexes such $\{N-[(1 R, 2 R)-1,2$-diphenylethyl-2-(3phenylpropylamino)]-4-methylbenzenesulfonamide\}ruthenium chloride (Scheme 2, compound 7) are known to be particularly effective catalysts, capable of performing the enantioselective reduction of ketones and imines through an asymmetric transfer hydrogenation (ATH) mechanism, illustrated in Scheme $3 .^{77}$ Further experiments using compounds carrying TsDPEN derivatives with one alkyl substituent on the basic nitrogens (Scheme 2, compound 8) have revealed the importance of the $\mathrm{N}-\mathrm{H}$ bond for ketone reduction. ${ }^{72}$ This is presumably due to lack of the $-N \mathrm{H} \cdots \mathrm{OC}$ interaction required for the postulated six membered cyclic transition state of the ketone reduction process (Scheme $3 \mathrm{a}$ ). ${ }^{73}$ The hydrides illustrated in Scheme 3 are known to be formed under the reaction conditions..$^{63,74,75}$ In contrast, compounds $\mathbf{8 / 8 a}$ are still effective 


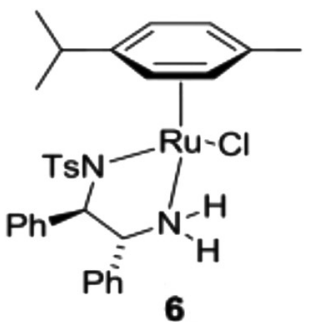

6

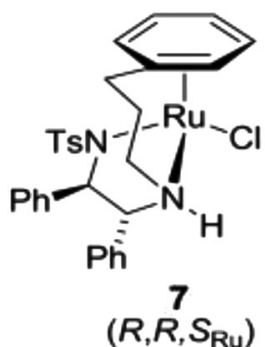

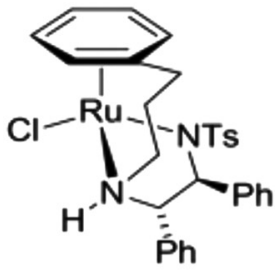

7a

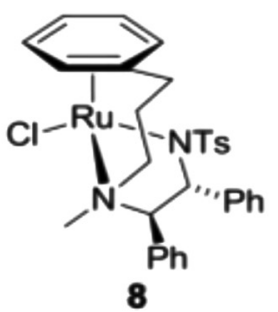

$\left(R, R, R_{\mathrm{Ru}}\right)$

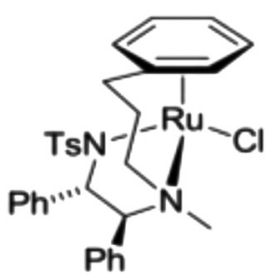

8 a

$\left(S, S, S_{\mathrm{Ru}}\right)$

Scheme 2 Half-sandwich Ru" complexes containing a TsDPEN ligand; complexes 7/7a and 8/8a were studied in this work.

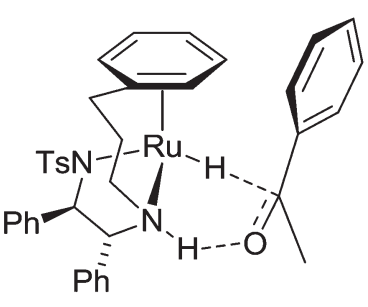

(A)

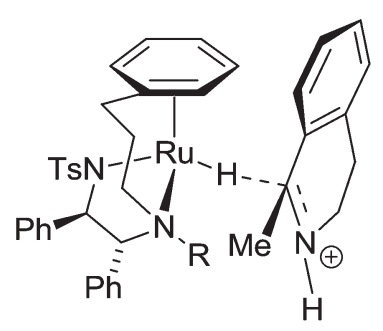

(B) $\mathrm{R}=\mathrm{H}$ or $\mathrm{Me}$
Scheme 3 (A) Mechanism of hydrogen transfer from the hydride derived from 7 to a ketone, in which the hydrogen bond from the $\mathrm{N}-\mathrm{H}$ is required for ketone reduction. Complex $\mathbf{8}$, lacking this $\mathrm{N}-\mathrm{H}$ bond, are inactive in ketone reduction. (B) Mechanism of hydrogen transfer from the hydride derived from 7 or 8 to an imine. The 'open' nature of the transition state, without an intramolecular hydrogen bond, allows both complexes to be effective in the reduction of imines. Complex 8 is, however, less active than 7 due to the additional steric hindrance imposed by the methyl group compared to a proton.

for imine reduction under similar conditions as predicted, but with lower reactivity when compared with catalysts $7 / 7$ a. As a result of these observations, coupled with studies reported by others, ${ }^{76,77}$ imine reduction is speculated to take place via the transition state illustrated in Scheme 3b. In this 'open' transition state, no $\mathrm{N}-\mathrm{H} \cdots \mathrm{N}=\mathrm{C}$ bond is present, hence the $\mathrm{N}$-alkylated catalysts 8 remain active. ${ }^{78}$ However, increased steric hindrance imposed by the larger methyl group (replacing the $\mathrm{H}$ atom) serve to lower their activity. Interestingly, the use of complexes 6 and 7 showing the same chiral configuration at the ligand for the reduction of ketones and imines results in formation of products of opposite configuration.

In recent years, the fast growing field of catalysis using ruthenium complexes has generated exciting new leads for anticancer research, e.g. the Hoveyda-Grubbs catalyst was demonstrated by Ott et al. to exhibit anticancer activity in MCF-7 breast and HT29 colon cancer cell lines. ${ }^{79}$ We also have recently reported a series of ruthenium complexes structurally similar to Noyori catalyst 6 that show anticancer properties in A2780 ovarian carcinoma cells. They reduce $\mathrm{NAD}^{+}$to $\mathrm{NADH}$ catalytically using formate as an hydride source, ${ }^{60}$ and their antiproliferative activity is markedly increased when cells are co-incubated with the complex and formate (Scheme 1, compound 5$)^{27}$

The only previous investigation of the anticancer activity of tethered complexes used the amine-tethered $\mathrm{Ru}^{\mathrm{II}}$ arene $\left[\eta^{6}: \eta^{1}\right.$ $\left.\left.\mathrm{C}_{6} \mathrm{H}_{5}\left(\mathrm{CH}_{2}\right)_{n} \mathrm{NH}_{2}\right) \mathrm{RuCl}_{2}\right]$ ( $n=2$ or 3 ). These complexes could form monofunctional adducts on DNA, but did not possess high anticancer activity in vitro. Here we explore the anticancer properties of catalytically active complexes $7 / 7 \mathbf{a}$ and $\mathbf{8 / 8 a}$. The tethered arene structure found in complexes 7 and $\mathbf{8}$ restricts the movement of the $\mathrm{N}, \mathrm{N}-\mathrm{ch}$ elated ligand TsDPEN within the coordination sphere of the stereogenic ruthenium centre. This greatly increases the conformational stability of the complexes and hence comparisons of the anticancer activity of the enantiomers may aid understanding of the role of chirality, if any, in the mode of action of this class of complexes.

\section{Results}

Complexes $\mathbf{7}$ and $\mathbf{8}$ (Scheme 2) are enantiomerically-pure and show different catalytic efficiency. Each of the four complexes illustrated in Scheme 2 exists predominantly in the diastereoisomeric form shown. To assign the chirality at each ruthenium centre, Cahn-Ingold-Prelog priority rules (CIP system) were used to define the priority sequence of ligands attached 
to the $\mathrm{Ru}^{\mathrm{II}}$ centre: $\eta^{6}-\mathrm{C}_{6}>\mathrm{Cl}>\mathrm{CHN}-\mathrm{Ts}>\mathrm{CHNH}$. According to the sequence rule of the $R / S$ system, the configurations of the $\mathrm{Ru}^{\mathrm{II}}$ centre in these four chiral ruthenium arene complexes are: $7=S_{\mathrm{Ru}}, 7 \mathbf{a}=R_{\mathrm{Ru}}, \mathbf{8}=R_{\mathrm{Ru}}, \mathbf{8 a}=S_{\mathrm{Ru}}$. The chirality details for the two pairs of ruthenium diastereoisomers are: $\left(S_{\mathrm{Ru}}, R_{\mathrm{C}}, R_{\mathrm{C}}\right)$ 7, $\left(R_{\mathrm{Ru}}, S_{\mathrm{C}}, S_{\mathrm{C}}\right)-7 \mathbf{a},\left(R_{\mathrm{Ru}}, R_{\mathrm{C}}, R_{\mathrm{C}}\right)-\mathbf{8}$ and $\left(S_{\mathrm{Ru}}, S_{\mathrm{C}}, S_{\mathrm{C}}\right)-\mathbf{8 a}$ (Table 1A).

\section{Antiproliferative activity}

The potential to inhibit the growth of cultured cancer cells provides a useful initial screening of anticancer activity. Table $1 \mathrm{~A}$ shows the ability of complexes 7 and 8 to inhibit the proliferation of A2780 human ovarian carcinoma cells $\left(\mathrm{GI}_{50}\right.$ values in $\mu \mathrm{M})$. It is notable that the most efficient catalysts show the least anticancer activity. Complexes 7 and 7a were 5-10 fold less active than $\mathbf{8}$ and $\mathbf{8 a}$, which were more active than cisplatin. Complexes containing the $R R$ isomers of the TsDPENbased chelated ligand showed better activity than complexes with the $S S$ isomer.

The four $\mathrm{Ru}^{\mathrm{II}}$ complexes were further tested in the NCI-60 panel. ${ }^{96,97}$ Their potency was comparable to that measured in A2780 cells (Tables 1B and S1†). Enantiomers 8 and 8a showed similar potency with the same mean $\mathrm{GI}_{50}$ value of $1.62 \mu \mathrm{M}$. This activity was similar to that of cisplatin (mean $\mathrm{GI}_{50}$ value $=$ $1.49 \mu \mathrm{M}$ ). However, 7 and $7 \mathbf{a}$ were much less active than $\mathbf{8 ,} 8 \mathbf{8}$ and cisplatin with mean $\mathrm{GI}_{50}$ values $>10 \mu \mathrm{M}$.

Table 1 (A) Chiral and biological properties of complexes 7/7a and 8/8a. (B) MG-MID (mean-graph midpoint) values for anticancer activity of 8 and $8 \mathrm{a}$ against the human tumour 60 -cell line panel: $\mathrm{Gl}_{50}$ (the concentration which inhibits cell growth by $50 \%$ ): TGI (the concentration which inhibits cell growth by $100 \%$ ); $L C_{50}$ (the concentration which kills $50 \%$ of the original cells)

(A)

\begin{tabular}{|c|c|c|c|c|}
\hline \multirow[b]{2}{*}{ Complex } & \multicolumn{2}{|c|}{ Chirality } & \multirow{2}{*}{$\begin{array}{l}\mathrm{GI}_{50} / \mu \mathrm{M} \\
(\mathrm{A} 2780)\end{array}$} & \multirow{2}{*}{$\begin{array}{l}\mathrm{IC}_{50} / \mu \mathrm{M} \text { (MT polymeris } \\
\text { ation inhibition) }\end{array}$} \\
\hline & Ligand & Metal & & \\
\hline 7 & $R, R$ & $S$ & $5.5 \pm 0.5$ & $1.1 \pm 0.1$ \\
\hline $7 a$ & $S, S$ & $R$ & $13.7 \pm 0.4$ & $1.5 \pm 0.2$ \\
\hline 8 & $R, R$ & $R$ & $1.2 \pm 0.3$ & $17 \pm 3$ \\
\hline $8 a$ & $S, S$ & $S$ & $1.8 \pm 0.2$ & $25 \pm 3$ \\
\hline Cisplatin & & & $2.0 \pm 0.2$ & \\
\hline Colchicine & & & & $1.4^{a}$ \\
\hline Vinblastine & & & & $0.13^{a}$ \\
\hline
\end{tabular}

(B)

\begin{tabular}{llll}
\hline Complex $^{b}$ & $\mathrm{GI}_{50}(\mu \mathrm{M})$ & $\mathrm{TGI}(\mu \mathrm{M})$ & $\mathrm{LC}_{50}(\mu \mathrm{M})$ \\
\hline 7 & $>10^{c}$ & NA & NA \\
$7 \mathbf{a}$ & $>10^{c}$ & NA & NA \\
$\mathbf{8}$ & 1.62 & 4.16 & 14.45 \\
8a & 1.62 & 4.07 & 18.62 \\
Cisplatin & 1.49 & 9.33 & 44.0
\end{tabular}

${ }^{a}$ Colchicine and vinblastine $\mathrm{IC}_{50}$ values reported previously. ${ }^{93}$ ${ }^{b}$ Complexes 7 and $7 a$ did not show significant antiproliferative activity (i.e. $\left.\mathrm{GI}_{50}>10 \mu \mathrm{M}\right)$ in the 60 cell lines tested by the NCI. Cisplatin data from NCI/DTP screening: March 2012, $48 \mathrm{~h}$ incubation. ${ }^{c}$ The maximum concentration tested by the NCI.

\section{GI $_{50}$ mean graphs}

Selectivity in the NCI-60 screen can be displayed in mean graphs, which plot positive and negative bars for each cell line relative to a central line which represents the mean $\mathrm{GI}_{50}$ (Fig. 1). Negative values projecting to the right represent higher cellular sensitivities for $\mathbf{8}$ or $\mathbf{8 a}$ compared with the mean value, whereas positive values projecting to the left represent lower cell line sensitivities for $\mathbf{8}$ or $\mathbf{8 a}$ compared to the average. It can be seen in Fig. 1 that the selectivities of $\mathbf{8}$ and $\mathbf{8 a}$ for the different cell lines are similar.

Complex 8 showed a broad spectrum of activity, with $\mathrm{GI}_{50}$ values ranging from 0.13 to $11.7 \mu \mathrm{M}$, with the highest activity in CCRF-CEM (leukemia), K-562 (leukemia), NCI-H522

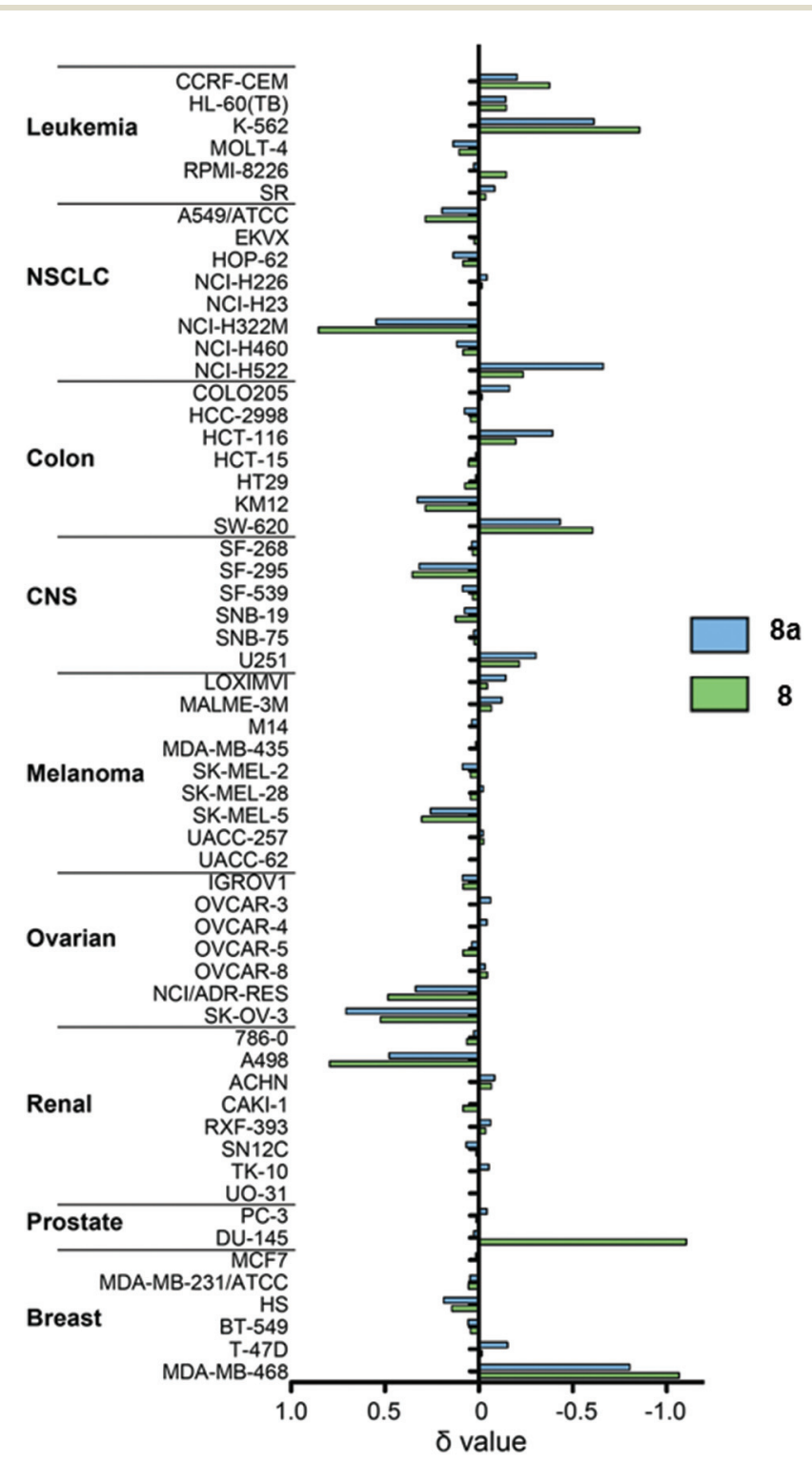

Fig. 1 Overlay of mean graphs for antiproliferative activity ( $G I_{50}$ values) of ruthenium complexes $\mathbf{8}$ and $\mathbf{8 a}$ in the $\mathrm{NCl}-60$ cell line screen. The positive and negative values are plotted along a vertical line that represents the mean response of all the cell lines in the panel to 8 and $\mathbf{8 a}$. Bars to the right (log scale) indicate activity higher than the mean. 
(non-small cell lung), SW-620 (colon), DU-145 (prostate) and MDA-MB-168 (breast) cell lines, with $\mathrm{GI}_{50}$ values in the $\mathrm{nM}-\mu \mathrm{M}$ range. The total growth inhibition (TGI) values ranged from 1.3 to $33.9 \mu \mathrm{M}$; and $50 \%$ lethal concentration $\left(\mathrm{LC}_{50}\right)$ values ranging from 3.7 to $>100 \mu \mathrm{M}$. Complex 8a also showed a broad spectrum of activity, with $\mathrm{GI}_{50}$ values ranging from 0.26 to $8.3 \mu \mathrm{M}$, with the highest anticancer activity in K-562 (leukemia), NCI-H522 (non-small cell lung), HCT-116 (colon), U251 (central nervous system) and MDA-MB-168 (breast) cell lines, again with $\mathrm{GI}_{50}$ values in the $\mathrm{nM}-\mu \mathrm{M}$ range. The TGI and $\mathrm{LC}_{50}$ values ranged from 1.6 to $21.6 \mu \mathrm{M}$ and $4.8 \mu \mathrm{M}$ to $>100 \mu \mathrm{M}$, respectively. In comparison, the renal cell lines in general showed low sensitivity to both $\mathbf{8}$ and $\mathbf{8 a}$. This is a common observation in screening as these cell lines are chemoresistant, likely owing to their high levels of multi-drug resistant proteins. ${ }^{80}$

\section{COMPARE analysis}

The patterns of sensitivity in the $\mathrm{GI}_{50}$, TGI and $\mathrm{LC}_{50}$ mean graphs for $\mathbf{8}$ and $\mathbf{8 a}$, were compared to the patterns of sensitivity for compounds populating the NCI/NIH databases using the COMPARE algorithm. ${ }^{97}$ The top 10 positive correlations in both the Standard Agents and Synthetic Agents database were considered, with Pearson correlation coefficients $(r)>0.6$. Tables S2 and $\mathrm{S} 3 \uparrow$ show the results of this analysis. The correlations are to an agent (mercaptoacetate) that can interact with (and in some cases cleave) DNA, to two agents that can interact with RNA machinery (rifamycin SV and caracemide), to one anti-angiogenic compound (withaferin A), and an agent which inhibits flavoproteinthioredoxin reductase (pleurotin). All other positive correlations were $<0.6$ and therefore not deemed significant. This analysis indicates that there are very few significant correlations with either database and therefore provides little insight into the mechanism of action (MoA). However, it does suggest that catalysts $\mathbf{8}$ and $\mathbf{8 a}$ have novel MoAs compared to the other compounds populating the NCI/ NIH database.

We assessed quantitatively the similarity in mean graphs of 8 and 8 a (Table $\mathrm{S} 4 \dagger$ ), giving correlation values at $0.868\left(\mathrm{GI}_{50}\right.$ mean graph), 0.945 (TGI mean graph) and $0.942\left(\mathrm{LC}_{50}\right.$ mean graph). These highly significant correlations confirm the observations in Fig. 1 and suggest that the mirror-image complexes $\mathbf{8}$ and $\mathbf{8 a}$ have the same MoA. The lack of correlation of activity for either of these compounds to the square-planar $\mathrm{Pt}^{\mathrm{II}}$ drug cisplatin confirms that even though they have similar potencies, their MoA is different, and is reflected in the A2780 and NCI-60 screening.

\section{Interactions with nucleobases and aqueous stability}

Since DNA is a potential target for transition metal anticancer drugs,${ }^{81,82}$ reactions of complex 8a with nucleobases 9-ethylguanine (9-EtG) and 9-methyladenine (9-MeA) were investigated by ${ }^{1} \mathrm{H}$ NMR spectroscopy. No reaction between these nucleobases and the Ru complex was observed after $24 \mathrm{~h}$ at $310 \mathrm{~K}$ (Fig. S1 and S2 $\dagger$ ). The NMR data showed that these DNA bases bind very weakly, and that the arene and $\mathrm{N}, \mathrm{N}^{\prime}$ - chelated ligands are strongly bound in aqueous solution. Substitution of the monodentate ligand would be expected to be facile since the 16-electron catalyst is known to be readily formed. $^{78}$

\section{Interactions with coenzyme NADH}

In recent years, a number of half-sandwich $\mathrm{Ru}^{\mathrm{II}}$, $\mathrm{Os}^{\mathrm{II}}$ arene and Ir ${ }^{\mathrm{III}}$ cyclopentadienyl anticancer complexes have been shown to oxidise reduced coenzyme NADH to $\mathrm{NAD}^{+}$with formation of corresponding metal hydride complexes. ${ }^{27,83,84}$ Consequently, reactions of complex 8a with NADH were investigated. However, no reaction between NADH and the complex was observed after $3 \mathrm{~h}$ at $298 \mathrm{~K}$ (Fig. S3 $\dagger$ ). In contrast, formation of a ruthenium hydride derived from $\mathbf{8}$ can be observed when the complex is treated with formic acid. ${ }^{78}$

However, the antiproliferative activity of complexes $7 / 8$ was increased by $5-25 \%$ upon co-incubation with sodium formate (Fig. S4 $\dagger$ ). This improvement is quite dramatic for complexes 7 and 7 a $(25 \%$ reduced cell proliferation when co-incubated with $2 \mathrm{mM}$ formate), but less significant for the less-efficient catalysts; 8 and $\mathbf{8 a}(5 \%)$.

\section{Cell cycle arrest}

Since complexes $7 / \mathbf{8}$ did not interact with the cellular targets previously observed for related ruthenium complexes, we analysed their effect over the cell cycle of A2780 cancer cells by propidium iodide staining and flow cytometry. Treatment with $2 \mu \mathrm{M} 7 / 8$ led to different effects; 7 and $7 \mathrm{a}$ induced S and G2/M arrest, while $\mathbf{8}$ and $8 \mathbf{a}$ arrested the cell cycle of A2780 in G2/M (Fig. 2).

\section{Cellular accumulation}

Cellular uptake plays an important role in antiproliferative activity. ${ }^{85}$ A2780 cells were treated for $24 \mathrm{~h}$ with different

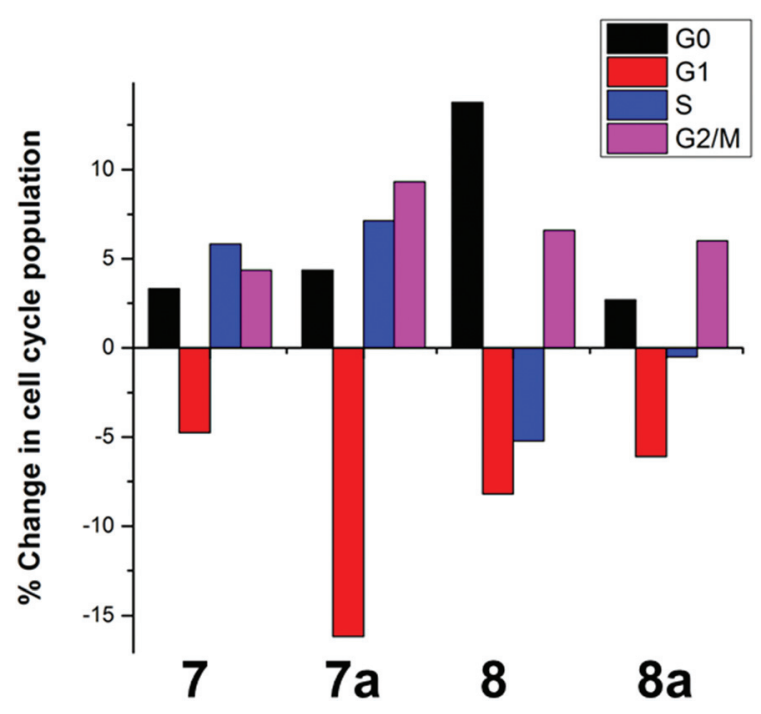

Fig. 2 Changes in the cell cycle of A2780 human ovarian carcinoma cells after $24 \mathrm{~h}$ treatment with $2 \mu \mathrm{M}$ of complexes $7,7 \mathrm{a}, 8$ and $8 \mathrm{a}$. 
concentrations ( $2 \mu \mathrm{M}$ or $\mathrm{GI}_{50}$ concentration) of complexes $\mathbf{7} / \mathbf{8}$, and the cell accumulation of Ru was measured using ICP-MS. Fig. 3 shows that $\mathbf{8}$ and $\mathbf{8 a}$ were accumulated to a much greater extent compared to 7 and $7 \mathbf{a}$ when cells were incubated with the same concentration of the complexes $(2 \mu \mathrm{M}$, Fig. 3A). Furthermore, A2780 cells accumulated similar amounts of $\mathrm{Ru}$ when treated with concentrations of the complexes that induced the same cell growth inhibition $\left(\mathrm{GI}_{50}\right.$ concentrations, Fig. 3B).

When the compartmentalisation of Ru within the cells was determined, we found that most of the Ru was in the cytosol, with less $\mathrm{Ru}$ located in the membranes (although significantly high amounts for $\mathbf{8}$ and $\mathbf{8 a}$ ) and in the cytoskeleton, and little in the nucleus (Fig. 4 and S5†). This finding also supports the conclusion that the complexes in this family do not target nuclear DNA, in contrast to e.g. ethylenediamine ruthenium arene anticancer complexes. ${ }^{41,42}$ Similar amounts of $\mathrm{Ru}$ from 8 and 8a were found in the various fractions when A2780 cells were treated with $\mathrm{GI}_{50}$ (1.2 and $1.8 \mu \mathrm{M}$, respectively) or $2 \mu \mathrm{M}$ concentrations (Fig. 4B), but significantly increased amounts of $\mathrm{Ru}$ from 7 and $7 \mathbf{a}$ when cells were treated with $\mathrm{GI}_{50}$ concentrations of 7 and $7 \mathbf{a}$, which are $2.8 \times$ and $6.9 \times$, respectively, higher than $2 \mu \mathrm{M}$ (Fig. 4A).

(A)

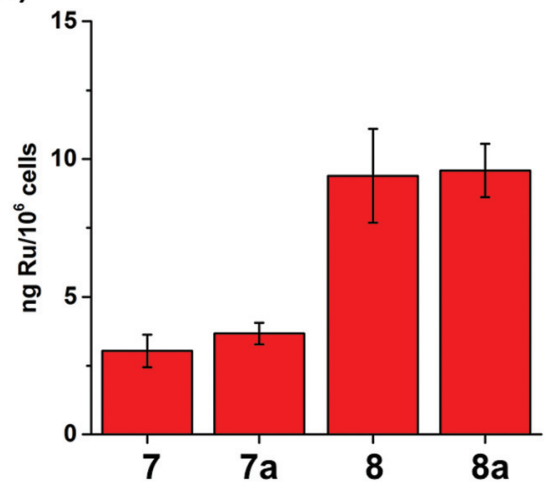

(B)

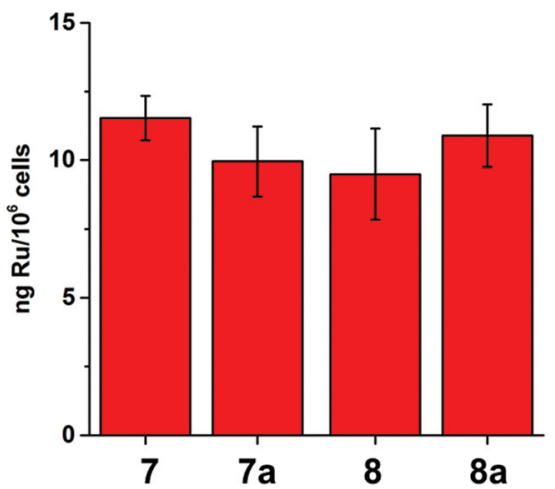

Fig. 3 Accumulation of Ru in A2780 human ovarian carcinoma cells (expressed as $\mathrm{ng} \mathrm{Ru} / 10^{6}$ cells) after $24 \mathrm{~h}$ treatment with (A) $2 \mu \mathrm{M}$ and (B) $\mathrm{Gl}_{50}$ concentrations of $7 / 7 \mathrm{a}$ or $8 / 8 \mathrm{a}$.
(A)

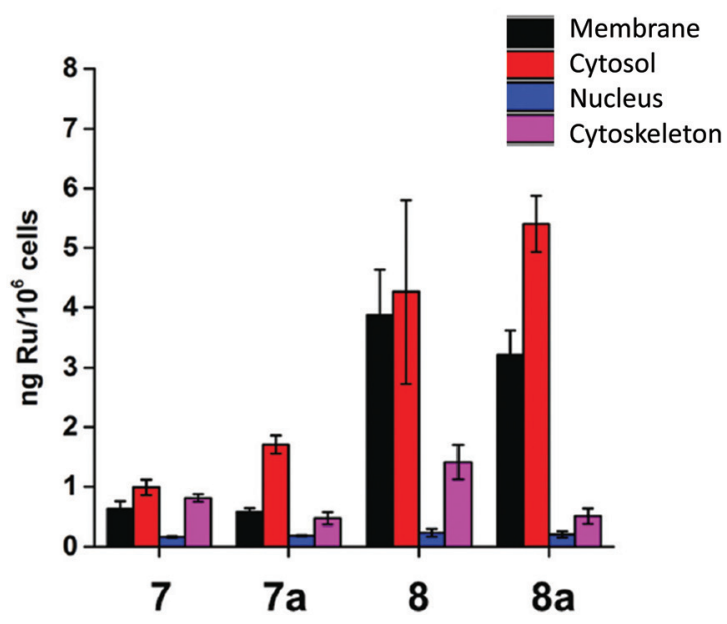

(B)

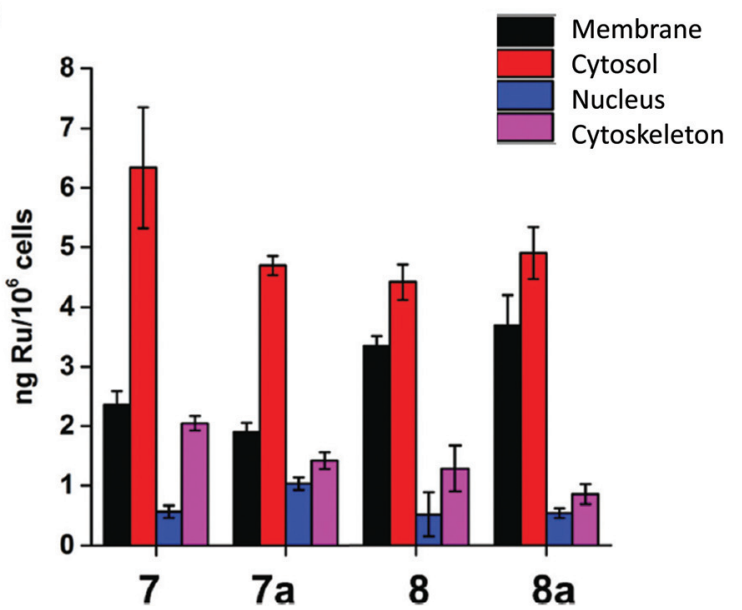

Fig. 4 Ru content of the cellular fractions of A2780 ovarian carcinoma cells (expressed in ng Ru/ $10^{6}$ cells) after $24 \mathrm{~h}$ treatment with (A) $2 \mu \mathrm{M}$ and (B) $\mathrm{Gl}_{50}$ concentrations of $7 / 8$.

\section{Microtubule polymerisation inhibition}

The data for cellular distribution show that cells treated with complexes $7 / 8$ accumulate up to $25 \%$ of the drug in the cytoskeletal fraction (Fig. 4, S5 and S6 $†$ ). This unusual pattern strongly indicates that complexes $\mathbf{7 / 8}$ may target cytoskeletal proteins including tubulin (protein component of microtubules), actin (component of microfilaments) and lamin (component of intermediate filaments). It is known that G2/M arrest can be induced by tubulin-targeting molecules; our flow cytometry analysis confirmed this suggestion (Fig. S7 $\dagger$ ). ${ }^{86,87}$ To test this hypothesis, we investigated the ability of complexes $7 / 8$ to affect tubulin polymerisation using a fluorescence-based assay. Fig. 5 and Table 1 show that $7 / 8$ inhibit tubulin polymerisation with potency following the trend $7>7 \mathbf{a}>\mathbf{8}>\mathbf{8 a}$. The $\mathrm{IC}_{50}$ values (concentrations which cause $50 \%$ polymerisation inhibition) vary from 1.1 to $15.3 \mu \mathrm{M}$ which is at the same order of magnitude as the $\mathrm{GI}_{50}$ values against cancer cell lines. More importantly, a correlation between the ability of the complexes to inhibit microtubule polymerisation, and the amount of 


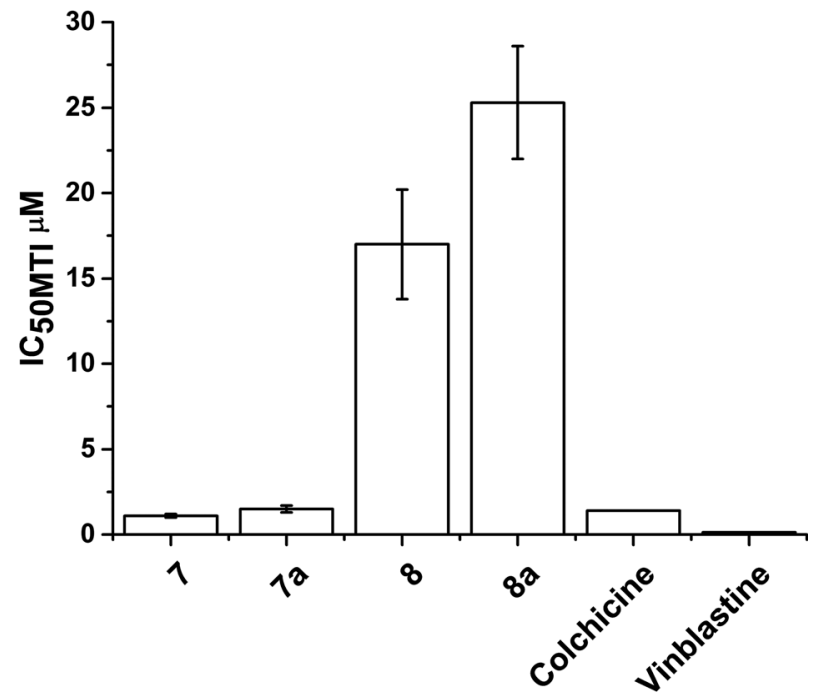

Fig. $5 \quad \mathrm{IC}_{50}$ values $(\mu \mathrm{M})$ for inhibition of microtubule polymerization inhibition (MTI) in vitro by complexes $7 / 8$ compared to colchicine and vinblastine (values taken from ref. 93).

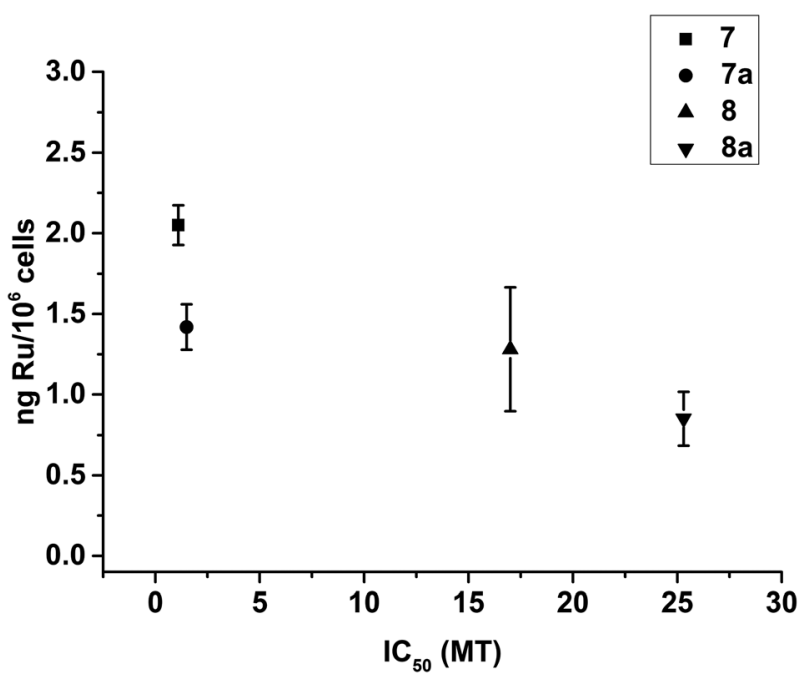

Fig. 6 Plot showing the correlation between the ability of complexes 7-8 to inhibit the microtubule polymerisation in vitro (expressed as $\left.\mathrm{IC}_{50} / \mu \mathrm{M}\right)$, and the amount of Ru found in the cytoskeleton of A2780 cells treated with $\mathrm{Gl}_{50}$ concentrations of the complexes (expressed as $\mathrm{ng}$ $\mathrm{Ru} / 10^{6}$ cells).

complex found in the cytoskeleton of treated cells (at $\mathrm{GI}_{50}$ concentration) is observed (Fig. 6).

\section{Discussion}

Our experiments show that 7-8 inhibit the proliferation of A2780 ovarian carcinoma cells with different efficiency. The $N$-methyl complexes $8\left(R_{\mathrm{Ru}}, R_{\mathrm{C}}, R_{\mathrm{C}}\right)$ and $\mathbf{8 a}\left(S_{\mathrm{Ru}}, S_{\mathrm{C}}, S_{\mathrm{C}}\right)$ are more active than cisplatin, whereas the $\mathrm{N}-\mathrm{H}$ complexes 7
$\left(S_{\mathrm{Ru}}, R_{\mathrm{C}}, R_{\mathrm{C}}\right)$ and $7 \mathbf{a}\left(R_{\mathrm{Ru}}, S_{\mathrm{C}}, S_{\mathrm{C}}\right)$ are less potent. The trend in the antiproliferative properties $(\mathbf{8}, \mathbf{8 a}>\mathbf{7}>\mathbf{7 a})$ is the inverse of that for catalytic activity. Remarkably, subtle structural differences between the four complexes result in dramatic differences in their anticancer activity.

(i) The $\mathrm{GI}_{50}$ values in A2780 ovarian carcinoma cells of $\left[\mathrm{Ru}\left(\eta^{6}\right.\right.$-benzene- $\left(\mathrm{CH}_{2}\right)_{3}$-TsDPEN- $\mathrm{N}$-X)Cl] complexes (7/8) increase up to an order of magnitude (5-13 $\mu \mathrm{M}$ for $7 / 7 \mathrm{a}$ compared to $1-2 \mu \mathrm{M}$ for $\mathbf{8 / 8 a}$ ) when the $\mathrm{N}-\mathrm{H}$ group located at the basic nitrogen atom in the $\left(\eta^{6}\right.$-benzene- $\left(\mathrm{CH}_{2}\right)_{3}$-TSDPEN- $\left.N-\mathrm{X}\right)$ chelating ligand (7/7a) is replaced by an $N$-methyl group (8/8a). A similar trend was also observed for the NCI-60 cell line panel; the mean $\mathrm{GI}_{50}$ values for 7 and 7 a were $>10 \mu \mathrm{M}$. This observation suggests that an $\mathrm{NH}$ group on the chelated ligand is not essential for antiproliferative activity, unlike the ethylenediamine series $\left[\mathrm{Ru}\left(\eta^{6}\right.\right.$-arene)(ethylenediamine) $\left.\mathrm{Cl}\right] \mathrm{PF}_{6}$ where it appears to play a role in H-bonding to the $\mathrm{C6O}$ of guanine when bound to DNA via N7. ${ }^{88}$

(ii) Although COMPARE analysis suggests that enantiomers probably have a similar mode of action, complexes containing $R R$-ligands (7 and 8) show higher activity than $S S$-isomers (7a and 8a), suggesting that ligand chirality influences their biological activity. Such effects might arise for example if (chiral) proteins are the targets. Additionally, the NCI-60 panel screening for $\mathbf{8}$ and $\mathbf{8 a}$ show that both enantiomers possess a differential selectivity towards individual cell lines (although they showed the same mean $\mathrm{GI}_{50}$ value).

This antiproliferative activity for $\mathbf{7 - 8}$ is not the result of the interaction of the complexes with $\mathrm{NADH}$ or nucleotides (as observed for structurally-related complexes). ${ }^{27,41,42}$ Perhaps it is not surprising that $\mathrm{Ru}$ centres which can form relatively stable 16-electron complexes (pseudo-5-coordinate) bind relatively weakly to $6^{\text {th }}$ ligands such as DNA bases. Nevertheless, a decrease in the proliferation of A2780 cells was observed when 7 and 8 were co-incubated with a hydride source (sodium formate) $;{ }^{60}$ suggesting that these compounds might be able to perform catalytic reactions inside cells. This increase in activity follows the trend previously observed for the catalytic properties of the complexes $(7 \gg 8)$, and is significant for 7 and $7 \mathbf{a}$ (25\% decrease in cell growth), making these complexes promising hydrogen-activated prodrugs. However, $\mathbf{8}$ and $\mathbf{8 a}$ are still more efficient in inhibiting the proliferation of A2780 cells, even in presence of sodium formate.

The difference in activity of 7 and 8 can be partially explained by differences in the cellular accumulation of the complexes. More $\mathrm{Ru}$ is found in A2780 ovarian carcinoma cells treated with $2 \mu \mathrm{M}$ of the more active $\mathbf{8}$ or $\mathbf{8 a}$ than in cells treated with the same concentration of the less active 7 or $7 \mathbf{a}$. Additionally, similar quantities of $\mathrm{Ru}$ were found in A2780 cells treated with $\mathrm{GI}_{50}$ concentrations of $7 / 7 \mathbf{a}$ or $\mathbf{8 / 8 a}$. The less efficient accumulation (perhaps uptake) of 7 and $7 \mathbf{a}$ by cells might be a key factor in lowering their antiproliferative activity.

The cellular targets for $7 / 8$ are most likely to be found in the cytosol of treated cells, where the drugs mainly accumulate. However, up to $25 \%$ of the Ru taken up by cells is found 
in the cytoskeleton (Fig. 4, S5 and S6†). Based on the cellular distribution data and G2/M phase cell cycle arrest observed, we hypothesised that targets could also be located in the cytoskeleton of the treated cells.

Microtubules are cycloskeletal polymers that show dynamic behaviour, polymerising and depolymerising multiple times upon hydrolysis of GTP. ${ }^{89}$ They form a scaffold that is in constant reorganisation, and yet serves as a stable source of polarity information across the cell, separating the replicated chromosomes between the two daughter cells during cell division through the formation of the mitotic spindle. ${ }^{90}$ This makes them important targets for the treatment of cancer, as disruption of the dynamic nature of microtubules stops cell proliferation and leads to apoptosis. Drugs such as taxanes (e.g. taxol) which stabilise microtubules and vinca alkaloids (e.g. vinblastine) which inhibit the formation of microtubules, are already used clinically as anticancer chemotherapeutic agents. ${ }^{91}$ The TsDPEN ligand in complexes $7 / 8$ shows structural similarities with the active conformation of a new series of light activated compounds capable of inhibiting the formation of microtubules by mimicking colchicine. ${ }^{92}$ Complexes 7 and $7 \mathbf{a}$ inhibit the polymerisation of microtubules in vitro $\left(\mathrm{IC}_{50}\right.$ of $1.1 \mu \mathrm{M}$ and $1.5 \mu \mathrm{M}$ ) as effectively as colchicine or vinblastine (clinically-used microtubule targeting antimitotic drugs; $\mathrm{GI}_{50}$ $1.4 \mu \mathrm{M}$, and $0.13 \mu \mathrm{M}$ respectively); ${ }^{93}$ whereas 8 and $8 \mathrm{a}$ are less potent $\left(\mathrm{GI}_{50}=40.6 \mu \mathrm{M}, 17 \mu \mathrm{M}\right.$ and $25.3 \mu \mathrm{M}$, respectively).

Furthermore, there is a correlation between the ability of the complexes to inhibit the polymerisation of microtubules in vitro and the quantity of $\mathrm{Ru}$ found in the cytoskeleton (Fig. 6). Our data indicate that $\mathbf{7 / 8}$ might be able to interact with microtubules in treated cells. This could lead to the observed G2/M phase cell cycle arrest, ultimately inhibiting proliferation of cells.

There is increasing interest in the activity of specific enantiomers of chiral tubulin-targeting agents. For example, natural colchicine has an a $S, 7 S$-absolute configuration, and is much more potent than its enantiomer. ${ }^{94}$ These data indicate the importance of the configuration of these agents. ${ }^{95}$ As found for the tethered Ru complexes studied in this work. Our results show that the chirality of the backbone or ruthenium centre individually is not critical for inhibiting tubulin polymerization. However, the combination of chiralities is important for maintaining the potency of these tethered ruthenium diastereoisomers. In addition, although 7 and $7 \mathbf{a}$ show stronger inhibition of tubulin polymerisation than 8 and $\mathbf{8 a}$, the trend is different from that of the antiproliferation. This suggests that other cellular targets, perhaps located in the cytosol or membranes of cells, could have an important role in the biological activity of such compounds.

\section{Conclusions}

Complexes $7 / 7 \mathbf{a}$ and $\mathbf{8 / 8 \mathbf { a }}$ are Noyori-like ruthenium arene transfer hydrogenation catalysts capable of the enantioselective reduction of ketones and imines through an ATH mechanism following the trend $\mathbf{7} \gg \mathbf{8}$ in catalytic efficiency. Our experiments show that their antiproliferative potency towards cancer cells follows the trend $\mathbf{8 ,} 8 \mathbf{8}>\mathbf{7}>\mathbf{7 a}$. Complex 7 carrying the $R R$ isomer of the TSDPEN derivative exhibits higher activity than the $S S$ derivative 7a. Unlike related 'piano-stool' ruthenium anticancer complexes, ${ }^{3,41,42}$ the antiproliferative potency of these Noyori-like ruthenium catalysts appears not to be related to their NADH catalytic activity or to DNA binding. The antiproliferative activity $\left(\mathrm{GI}_{50}\right.$ values) of $7 / 7 \mathbf{a}$ and $\mathbf{8 / 8 \mathbf { a }}$ appears to be related to their ability to accumulate in cancer cells, and is at least partially linked to their accumulation in the cytoskeleton, and inhibition of the polymerisation of microtubules.

\section{Methods}

\section{Materials}

Complexes $7 / 8$ were synthesised as previously described. ${ }^{75,92}$ The A2780 human ovarian carcinoma cell line was purchased from European Collection of Animal Cell Cultures (ECACC), Salisbury, UK), RPMI-1640, as well as, foetal bovine serum, L-glutamine, penicillin/streptomycin mixture, trypsin, trypsin/ EDTA, phosphate buffered saline (PBS) were purchased from GE Healthcare. Propidium iodide (>94\%) and RNAse A were obtained from Sigma Aldrich.

\section{Cell culture}

A2780 human ovarian carcinoma cells were used between passages 5 and 18 and grown in Roswell Park Memorial Institute medium (RPMI-1640) supplemented with $10 \%$ of foetal calf serum, $1 \%$ of $2 \mathrm{mM}$ glutamine and $1 \%$ penicillin/streptomycin. They were grown as adherent monolayers at $310 \mathrm{~K}$ in a $5 \% \mathrm{CO}_{2}$ humidified atmosphere and passaged at approximately $70-80 \%$ confluence.

\section{In vitro growth inhibition assays}

The antiproliferative activity of complexes 7-8 was determined in A2780 ovarian cancer cells. Briefly, 96-well plates were used to seed 5000 cells per well. The plates were left to pre-incubate with drug-free medium at $310 \mathrm{~K}$ for $48 \mathrm{~h}$ before adding different concentrations of the compounds to be tested. A drug exposure period of $24 \mathrm{~h}$ was allowed. After this, supernatants were removed by suction and each well was washed with PBS. A further $48 \mathrm{~h}$ was allowed for the cells to recover in drug-free medium at $310 \mathrm{~K}$. The SRB assay was used to determine cell viability. $\mathrm{GI}_{50}$ values, as the concentration which causes $50 \%$ cell death, were determined as duplicates of triplicates in two independent sets of experiments and their standard deviations were calculated.

\section{Cell viability modulation by co-administration of sodium} formate

Cell viability assays were carried out with complexes $7 / 8$ in A2780 ovarian cancer cells, as described above with the following modifications: a fixed concentration of each $\mathrm{Ru}$ complex 
equal to $1 / 5 \mathrm{GI}_{50}$ was used in co-administration with three different concentrations of sodium formate or sodium acetate $(0.5,1.0$ and $2.0 \mathrm{mM})$. To prepare the stock solution of the drug, the complex was dissolved in 5\% DMSO and, diluted in a $1: 1$ mixture of $0.9 \%$ saline : cell culture medium. This stock was further diluted using RPMI-1640 until working concentrations were achieved. Separately, stock solutions of sodium formate were prepared in saline. The complex and formate were added to each well independently, but within 5 min of each other. The SRB assay was used to determine cell viability. Cell proliferation was studied as duplicates of triplicates in two independent sets of experiments and their standard deviations were calculated.

\section{NCI-60 cell screening}

The protocols used in the National Cancer Institute (NCI) screens have been described previously. ${ }^{96}$ Briefly, cells were treated with complex for $48 \mathrm{~h}$ at five concentrations ranging from 0.01 to $100 \mu \mathrm{M}$. Three endpoints were calculated: $\mathrm{GI}_{50}$ (the concentration to inhibit cell growth by $50 \%$ ): TGI (the concentration to inhibit cell growth by $100 \%$ ), $\mathrm{LC}_{50}$ (the concentration which kills $50 \%$ of the original cell count), MG-MID (full-panel mean-graph midpoint). The data reported for cisplatin were from the most up-to-date NCI/DTP screening conducted in March 2012.

\section{Mean graphs and COMPARE analysis}

Mean graphs were constructed by plotting positive and negative values along a vertical line, representing the mean response over all cell lines in the panel (mean $\mathrm{GI}_{50}$ ). This is calculated in 3 steps: (1) the $\mathrm{GI}_{50}$ value for each cell line tested against each compound is converted to its corresponding $\log _{10}$ $\mathrm{GI}_{50}$ value; (2) $\log _{10} \mathrm{GI}_{50}$ values are averaged; (3) each $\log _{10} \mathrm{GI}_{50}$ value is subtracted from the average to create a delta value. These positive and negative deltas are plotted along a vertical line which represents the mean response of all the 60 cell lines in the NCI panel. Projections to the right indicate cell lines with susceptibility that exceeds the mean, projections to the left indicate cell lines with lower susceptibility. The COMPARE analysis quantitatively compares the mean graph patterns of compounds against the NCI/DTP Standard Agents Database (a collection of 171 known anticancer compounds to provide preliminary indications on a possible mechanism of action) and the Synthetic Agents Database (>40 000 pure natural and synthetic compounds). ${ }^{97}$ For this analysis, we assessed the top 10 returned hits in each database, for positive and negative correlations. High positive Pearson correlations $(r \geq 0.6)$ to agents in each database may indicate similar anti-cancer mechanism.

\section{Interactions with nucleobases}

The reaction of complex $8 \mathbf{a}(1.5 \mathrm{mM})$ with the nucleobases 9-ethylguanine (9-EtG) and 9-methyladenine (9-MeA) typically involved addition of a solution containing $1 \mathrm{~mol}$ equiv. of nucleobase in $\mathrm{D}_{2} \mathrm{O}$ to an equilibrium solution of complex $\mathbf{8 a}$ in $25 \% \mathrm{MeOD}-d_{4} / 75 \% \mathrm{D}_{2} \mathrm{O}(\mathrm{v} / \mathrm{v}) .{ }^{1} \mathrm{H}$ NMR spectra of these solutions were recorded at $310 \mathrm{~K}$ after $10 \mathrm{~min}$ and $24 \mathrm{~h}$.

\section{Interactions with NADH}

The reaction of complex $8 \mathrm{a}(1.5 \mathrm{mM})$ with $\mathrm{NADH}$ typically involved addition of a solution containing $3 \mathrm{~mol}$ equiv. of $\mathrm{NADH}$ in $\mathrm{H}_{2} \mathrm{O}$ to an equilibrium solution of complex 8a in $25 \% \mathrm{MeOD}-d_{4} / 75 \% \mathrm{H}_{2} \mathrm{O}(\mathrm{v} / \mathrm{v}) .{ }^{1} \mathrm{H}$ NMR spectra of these solutions were recorded at $298 \mathrm{~K}$ after $10 \mathrm{~min}$ and $3 \mathrm{~h}$.

\section{Ruthenium accumulation in whole cancer cells}

Cell accumulation studies for metal complexes 7 and 8 were conducted on A2780 ovarian cells. Briefly, $10 \times 10^{6}$ cells were seeded on $145 \mathrm{~mm}$ petri dishes. After $24 \mathrm{~h}$ of pre-incubation time in drug-free medium at $310 \mathrm{~K}$, the complexes were added to give final concentrations equal to $\mathrm{GI}_{50}$ or $2 \mu \mathrm{M}$ and a further $24 \mathrm{~h}$ of drug exposure was allowed. After this time, cells were treated with trypsin, counted, and cell pellets were collected. Each pellet was digested overnight in concentrated nitric acid $(73 \%)$ at $353 \mathrm{~K}$; the resulting solutions were diluted with double-distilled water to a final concentration of $5 \% \mathrm{HNO}_{3}$ and the amount of Ru taken up by the cells was determined by ICP-MS (Agilent technologies 7500 series). Data acquisition was carried out in ICP-MS top B.03.05 and analysis on offline Data analysis B.03.05). These experiments did not include any cell recovery time in drug-free media; they were carried out in triplicate and the standard deviations were calculated.

\section{Ruthenium distribution in cancer cells}

Cell pellets were obtained as described above, and were fractionated using the Fraction PREP kit from BioVision according to the supplier's instructions. Each sample was digested overnight in concentrated nitric acid (73\%) and the amount of $\mathrm{Ru}$ taken up by the cells was determined by ICP-MS. Data acquisition was carried out in ICP-MS top B.03.05 and analysis on offline Data analysis B.03.05). These experiments were all carried out in triplicate and the standard deviations were calculated.

\section{Cell cycle analysis}

A2780 ovarian cancer cells were seeded in a 6-well plate using $1.0 \times 10^{6}$ cells per well. They were pre-incubated in drug-free media at $310 \mathrm{~K}$ for $24 \mathrm{~h}$, after which complexes were added at concentrations equal to $2 \mu \mathrm{M}$ (or $100 \mathrm{nM}$ for Colchicine and Taxol controls). After $24 \mathrm{~h}$ of drug exposure, supernatants were removed by suction and cells were washed with PBS. Finally, cells were harvested using trypsin. DNA staining was achieved after cold ethanol fixation by re-suspending the cell pellets in PBS containing propidium iodide (PI) and RNAse A. Cell pellets were re-suspended in PBS before being analysed by flow cytometry using the maximum excitation of PI-bound DNA at $536 \mathrm{~nm}$, and its emission at $617 \mathrm{~nm}$. Data were processed using Flowjo software. These experiments were carried out in triplicate, although only selected histograms are shown, full numerical data and statistical analysis can be found in the ESI. $\dagger$

\section{Microtubule polymerisation assays}

The effect of complexes 7 and $\mathbf{8}$ on tubulin polymerisation was determined using a fluorescence-based tubulin polymerisation 
assay (BK011P; Cytoskeleton, Inc.) according to the supplier's instructions. Measurements were performed in a plate reader GloMax®-Multi+ Detection System with Temperature Control (E9032; Promega) equipped with a fluorescence module (E8051; Promega) using the UV fluorescence optical kit $\left(\lambda_{\text {exc }}\right.$ $\left.365 \mathrm{~nm} ; \lambda_{\mathrm{em}} 410-460 \mathrm{~nm}\right) . \mathrm{IC}_{50}$ values, as the concentration which causes $50 \%$ polymerisation inhibition, were determined as duplicates.

\section{Acknowledgements}

We thank the ERC (grant no. 247450 BIOINCMED), EPSRC (grant no. EP/F034210/1) and Science City/EU ERDF/AWM (MaXis mass spectrometer and the X-ray diffractometer) for funding. Dr Michael Khan (Life Sciences) for provision of facilities for cell culture and the National Cancer Institute (NCI) for 60-cancer-cell-line screening. We also thank Warwick University for support of Rina Soni and Ying Fu through Warwick Postgraduate Research Studentships, and the BBSRC for support of Jessica Hearn (PhD studentship).

\section{References}

1 B. K. Keppler, M. Henn, U. M. Juhl, M. R. Berger, R. Niebl and F. E. Wagner, in Ruthenium and Other Non-Platinum Metal Complexes in Cancer Chemotherapy, Springer, Berlin, Heidelberg, 1989, vol. 10, pp. 41-69.

2 A. Bergamo, S. Zorzet, B. Gava, A. Sorc, E. Alessio, E. Iengo and G. Sava, Anticancer Drugs, 2000, 11, 665-672.

3 M. Gras, B. Therrien, G. Süss-Fink, A. Casini, F. Edafe and P. J. Dyson, J. Organomet. Chem., 2010, 695, 1119-1125.

4 Y. Geldmacher, M. Oleszak and W. S. Sheldrick, Inorg. Chim. Acta, 2012, 393, 84-102.

5 A. M. Krause-Heuer, P. Leverett, A. Bolhuis and J. R. Aldrich-Wright, Aust. J. Chem., 2012, 65, 860-873.

6 M. Carreira, R. Calvo-Sanjuán, M. Sanaú, I. Marzo and M. Contel, Organometallics, 2012, 31, 5772-5781.

7 A. Kastl, A. Wilbuer, A. L. Merkel, L. Feng, P. Di Fazio, M. Ocker and E. Meggers, Chem. Commun., 2012, 48, 18631865.

8 J. M. Hearn, I. Romero-Canelón, B. Qamar, Z. Liu, I. Hands-Portman and P. J. Sadler, ACS Chem. Biol., 2013, 8, 1335-1343.

9 R. Cao, J. Jia, X. Ma, M. Zhou and H. Fei, J. Med. Chem., 2013, 56, 3636-3644.

10 X. Song, Y. Qian, R. Ben, X. Lu, H.-L. Zhu, H. Chao and J. Zhao, J. Med. Chem., 2013, 56, 6531-6535.

11 K. Suntharalingam, T. C. Johnstone, P. M. Bruno, W. Lin, M. T. Hemann and S. J. Lippard, J. Am. Chem. Soc., 2013, 135, 14060-14063.

12 J. Maksimoska, D. S. Williams, G. E. Atilla-Gokcumen, K. S. M. Smalley, P. J. Carroll, R. D. Webster, P. Filippakopoulos, S. Knapp, M. Herlyn and E. Meggers, Chem. - Eur. J., 2008, 14, 4816-4822.
13 Y. Fu, A. Habtemariam, A. M. Pizarro, S. H. van Rijt, D. J. Healey, P. A. Cooper, S. D. Shnyder, G. J. Clarkson and P. J. Sadler, J. Med. Chem., 2010, 53, 8192-8196.

14 D. Wang and S. J. Lippard, Nat. Rev. Drug Discovery, 2005, 4, 307-320.

15 J. Z. Zhang, N. S. Bryce, A. Lanzirotti, C. K. J. Chen, D. Paterson, M. D. de Jonge, D. L. Howard and T. W. Hambley, Metallomics, 2012, 4, 1209-1217.

16 G. Y. Park, J. J. Wilson, Y. Song and S. J. Lippard, Proc. Natl. Acad. Sci. U. S. A., 2012, 109, 11987-11992.

17 P. J. Bednarski, K. Korpis, A. F. Westendorf, S. Perfahl and R. Grünert, Philos. Trans. R. Soc., A, 2013, 371, 20120118.

18 L. Messori, A. Casini, C. Gabbiani, E. Michelucci, L. Cubo, C. Ríos-Luci, J. M. Padrón, C. Navarro-Ranninger and A. G. Quiroga, ACS Med. Chem. Lett., 2010, 1, 381-385.

19 G. Gasser and N. Metzler-Nolte, Curr. Opin. Chem. Biol., 2012, 16, 84-91.

20 C. G. Hartinger and P. J. Dyson, Chem. Soc. Rev., 2009, 38, 391-401.

21 I. Bratsos, E. Mitri, F. Ravalico, E. Zangrando, T. Gianferrara, A. Bergamo and E. Alessio, Dalton Trans., 2012, 41, 7358-7371.

22 G. S. Smith and B. Therrien, Dalton Trans., 2011, 40, 10793-10800.

23 V. Brabec and O. Nováková, Drug Resist. Updates, 2006, 9, 111-122.

24 A. Bergamo and G. Sava, Dalton Trans., 2011, 40, 78177823.

25 G. Suss-Fink, Dalton Trans., 2010, 39, 1673-1688.

26 C. G. Hartinger, N. Metzler-Nolte and P. J. Dyson, Organometallics, 2012, 31, 5677-5685.

27 J. J. Soldevila-Barreda, I. Romero-Canelon, A. Habtemariam and P. J. Sadler, Nat. Commun., 2015, 6, 6582.

28 W. H. Ang, Z. Grote, R. Scopelliti, L. Juillerat-Jeanneret, K. Severin and P. J. Dyson, J. Organomet. Chem., 2009, 694, 968-972.

29 V. B. Arion, A. Dobrov, S. Goschl, M. A. Jakupec, B. K. Keppler and P. Rapta, Chem. Commun., 2012, 48, 8559-8561.

30 W. Kandioller, C. G. Hartinger, A. A. Nazarov, C. Bartel, M. Skocic, M. A. Jakupec, V. B. Arion and B. K. Keppler, Chem. - Eur. J., 2009, 15, 12283-12291.

31 S. Das, S. Sinha, R. Britto, K. Somasundaram and A. G. Samuelson, J. Inorg. Biochem., 2010, 104, 93-104.

32 S. M. Meier, M. Novak, W. Kandioller, M. A. Jakupec, V. B. Arion, N. Metzler-Nolte, B. K. Keppler and C. G. Hartinger, Chem. - Eur. J., 2013, 19, 9297-9307.

33 F. Barragán, P. López-Senín, L. Salassa, S. Betanzos-Lara, A. Habtemariam, V. Moreno, P. J. Sadler and V. Marchán, J. Am. Chem. Soc., 2011, 133, 14098-14108.

34 K. S. M. Smalley, R. Contractor, N. K. Haass, A. N. Kulp, G. E. Atilla-Gokcumen, D. S. Williams, H. Bregman, K. T. Flaherty, M. S. Soengas, E. Meggers and M. Herlyn, Cancer Res., 2007, 67, 209-217.

35 H. Chen, J. A. Parkinson, S. Parsons, R. A. Coxall, R. O. Gould and P. J. Sadler, J. Am. Chem. Soc., 2002, 124, 3064-3082. 
36 C. Scolaro, A. Bergamo, L. Brescacin, R. Delfino, M. Cocchietto, G. Laurenczy, T. J. Geldbach, G. Sava and P. J. Dyson, J. Med. Chem., 2005, 48, 4161-4171.

37 W. Han Ang and P. J. Dyson, Eur. J. Inorg. Chem., 2006, 2006, 4003-4018.

38 W. F. Schmid, R. O. John, V. B. Arion, M. A. Jakupec and B. K. Keppler, Organometallics, 2007, 26, 6643-6652.

39 A. K. Renfrew, A. D. Phillips, E. Tapavicza, R. Scopelliti, U. Rothlisberger and P. J. Dyson, Organometallics, 2009, 28, 5061-5071.

40 Y. Lin, Y. Huang, W. Zheng, F. Wang, A. Habtemariam, Q. Luo, X. Li, K. Wu, P. J. Sadler and S. Xiong, J. Inorg. Biochem., 2013, 128, 77-84.

41 L. Oehninger, M. Stefanopoulou, H. Alborzinia, J. Schur, S. Ludewig, K. Namikawa, A. Munoz-Castro, R. W. Koster, K. Baumann, S. Wolfl, W. S. Sheldrick and I. Ott, Dalton Trans., 2013, 42, 1657-1666.

42 A. A. Nazarov, D. Gardini, M. Baquie, L. Juillerat-Jeanneret, T. P. Serkova, E. P. Shevtsova, R. Scopelliti and P. J. Dyson, Dalton Trans., 2013, 42, 2347-2350.

43 R. Mitra, S. Das, S. Shinde, S. Sinha, K. Somasundaram and A. G. Samuelson, Chem. - Eur. J., 2012, 18, 1227812291.

44 W. H. Ang, E. Daldini, C. Scolaro, R. Scopelliti, L. JuilleratJeannerat and P. J. Dyson, Inorg. Chem., 2006, 45, 90069013.

45 W. Ginzinger, G. Mühlgassner, V. B. Arion, M. A. Jakupec, A. Roller, M. Galanski, M. Reithofer, W. Berger and B. K. Keppler, J. Med. Chem., 2012, 55, 3398-3413.

46 S. J. Lucas, R. M. Lord, R. L. Wilson, R. M. Phillips, V. Sridharan and P. C. McGowan, Dalton Trans., 2012, 41, 13800-13802.

47 F. Schmitt, N. P. E. Barry, L. Juillerat-Jeanneret and B. Therrien, Bioorg. Med. Chem. Lett., 2012, 22, 178-180.

48 Q. Wu, C. Fan, T. Chen, C. Liu, W. Mei, S. Chen, B. Wang, Y. Chen and W. Zheng, Eur. J. Med. Chem., 2013, 63, 57-63.

49 A. Valente, M. H. Garcia, F. Marques, Y. Miao, C. Rousseau and P. Zinck, J. Inorg. Biochem., 2013, 127, 79-81.

50 I. Romero-Canelón, L. Salassa and P. J. Sadler, J. Med. Chem., 2013, 56, 1291-1300.

51 L. He, S.-Y. Liao, C.-P. Tan, R.-R. Ye, Y.-W. Xu, M. Zhao, L.-N. Ji and Z.-W. Mao, Chem. - Eur. J., 2013, 19, 1215212160.

52 N. P. E. Barry, O. Zava, J. Furrer, P. J. Dyson and B. Therrien, Dalton Trans., 2010, 39, 5272-5277.

53 A. Dubey, J. W. Min, H. J. Koo, H. Kim, T. R. Cook, S. C. Kang, P. J. Stang and K.-W. Chi, Chem. - Eur. J., 2013, 19, 11622-11628.

54 A. Mishra, H. Jung, J. W. Park, H. K. Kim, H. Kim, P. J. Stang and K.-W. Chi, Organometallics, 2012, 31, 3519-3526.

55 N. Uematsu, A. Fujii, S. Hashiguchi, T. Ikariya and R. Noyori, J. Am. Chem. Soc., 1996, 118, 4916-4917.

56 T. Ohkuma, N. Utsumi, K. Tsutsumi, K. Murata, C. Sandoval and R. Noyori, J. Am. Chem. Soc., 2006, 128, 8724-8725.
57 S. Hashiguchi, A. Fujii, J. Takehara, T. Ikariya and R. Noyori, J. Am. Chem. Soc., 1995, 117, 7562-7563.

58 R. Noyori and S. Hashiguchi, Acc. Chem. Res., 1997, 30, 97-102.

59 Y. Yan, M. Melchart, A. Habtemariam, A. A. Peacock and P. Sadler, J. Biol. Inorg. Chem., 2006, 11, 483-488.

60 J. J. Soldevila-Barreda, P. C. A. Bruijnincx, A. Habtemariam, G. J. Clarkson, R. J. Deeth and P. J. Sadler, Organometallics, 2012, 31, 5958-5967.

61 M. Ito, T. Ootsuka, R. Watari, A. Shiibashi, A. Himizu and T. Ikariya, J. Am. Chem. Soc., 2011, 133, 4240-4242.

62 J. Hannedouche, G. J. Clarkson and M. Wills, J. Am. Chem. Soc., 2004, 126, 986-987.

63 K.-J. Haack, S. Hashiguchi, A. Fujii, T. Ikariya and R. Noyori, Angew. Chem., Int. Ed. Engl., 1997, 36, 285288.

64 H.-K. Liu, S. J. Berners-Price, F. Wang, J. A. Parkinson, J. Xu, J. Bella and P. J. Sadler, Angew. Chem., Int. Ed., 2006, 118, 8333-8336.

65 F. Wang, A. Habtemariam, E. P. L. van der Geer, R. Fernández, M. Melchart, R. J. Deeth, R. Aird, S. Guichard, F. P. A. Fabbiani, P. Lozano-Casal, I. D. H. Oswald, D. I. Jodrell, S. Parsons and P. J. Sadler, Proc. Natl. Acad. Sci. U. S. A., 2005, 102, 18269-18274.

66 T. Ikariya, K. Murata and R. Noyori, Org. Biomol. Chem., 2006, 4, 393-406.

67 S. Gladiali and E. Alberico, Chem. Soc. Rev., 2006, 35, 226236.

68 T. Ikariya and A. J. Blacker, Acc. Chem. Res., 2007, 40, 13001308.

69 J. K. Barton and E. Lolis, J. Am. Chem. Soc., 1985, 107, 708709.

70 C. Qian, J.-Q. Wang, C.-L. Song, L.-L. Wang, L.-N. Ji and H. Chao, Metallomics, 2013, 5, 844-854.

71 D. Sun, Y. Liu, D. Liu, R. Zhang, X. Yang and J. Liu, Chem. - Eur. J., 2012, 18, 4285-4295.

72 B. Zhao, Z. Han and K. Ding, Angew. Chem., Int. Ed., 2013, 52, 4744-4788.

73 J. E. Martins, G. J. Clarkson and M. Wills, Org. Lett., 2009, 11, 847-850.

74 D. A. Alonso, P. Brandt, S. J. M. Nordin and P. G. Andersson, J. Am. Chem. Soc., 1999, 121, 9580-9588.

75 M. Yamakawa, H. Ito and R. Noyori, J. Am. Chem. Soc., 2000, 122, 1466-1478.

76 L. Evanno, J. Ormala and P. M. Pihko, Chem. - Eur. J., 2009, 15, 12963-12967.

77 M. R. Ringenberg and T. R. Ward, Chem. Commun., 2011, 47, 8470-8476.

78 R. Soni, F. K. Cheung, G. C. Clarkson, J. E. D. Martins, M. A. Graham and M. Wills, Org. Biomol. Chem., 2011, 9, 3290-3294.

79 L. Oehninger, H. Alborzinia, S. Ludewig, K. Baumann, S. Wölfl and I. Ott, ChemMedChem, 2011, 6, 2142-2145.

80 D. Türk, M. D. Hall, B. F. Chu, J. A. Ludwig, H. M. Fales, M. M. Gottesman and G. Szakács, Cancer Res., 2009, 69, 8293-8301. 
81 J.-H. Wen, C.-Y. Li, Z.-R. Geng, X.-Y. Ma and Z.-L. Wang, Chem. Commun., 2011, 47, 11330-11332.

82 J. Reedijk, Metallomics, 2012, 4, 628-632.

83 S. Betanzos-Lara, Z. Liu, A. Habtemariam, A. M. Pizarro, B. Qamar and P. J. Sadler, Angew. Chem., Int. Ed., 2012, 51, 3897-3900.

84 Y. Fu, M. J. Romero, A. Habtemariam, M. E. Snowden, L. Song, G. J. Clarkson, B. Qamar, A. M. Pizarro, P. R. Unwin and P. J. Sadler, Chem. Sci., 2012, 3, 24852494.

85 Y. Fu, A. Habtemariam, A. M. Basri, D. Braddick, G. J. Clarkson and P. J. Sadler, Dalton Trans., 2011, 40, 10553-10562.

86 K. C. Morrison and P. J. Hergenrother, Anal. Biochem., 2012, 420, 26-32.

87 S. Tcherniuk, S. Deshayes, V. Sarli, G. Divita and A. Abrieu, Chem. Biol., 2011, 18, 631-641.

88 H. Chen, J. A. Parkinson, S. Parsons, R. A. Coxall, R. O. Gould and P. J. Sadler, J. Am. Chem. Soc., 2002, 124, 3064-3082.

89 T. Hawkins, M. Mirigian, M. S. Yasar and J. L. Ross, J. Biomech., 2010, 43, 23-30.
90 E. Karsenti and I. Vernos, Science, 2001, 294, 543547.

91 M. A. Jordan and L. Wilson, Nat. Rev. Cancer, 2004, 4, 253265.

92 M. Borowiak, W. Nahaboo, M. Reynders, K. Nekolla, P. Jalinot, J. Hasserodt, M. Rehberg, M. Delattre, S. Zahler, A. Vollmar, D. Trauner and O. Thorn-Seshold, Cell, 2015, 162, 403-411.

93 H. Prinz, P. Schmidt, K. J. Bohm, S. Baasner, K. Muller, E. Unger, M. Gerlach and E. G. Gunther, J. Med. Chem., 2009, 52, 1284-1294.

94 Q. Shi, P. VerdierPinard, A. Brossi, E. Hamel, A. T. McPhail and K. H. Lee, J. Med. Chem., 1997, 40, 961966.

95 R. Bai, M. C. Roach, S. K. Jayaram, J. Barkoczy, G. R. Pettit, R. F. Luduena and E. Hamel, Biochem. Pharmacol., 1993, 45, 1503-1515.

96 S. L. Holbeck, J. M. Collins and J. H. Doroshow, Mol. Cancer Ther., 2010, 9, 1451-1460.

97 K. D. Paull, R. H. Shoemaker, L. Hodes, A. Monks, D. A. Scudiero, L. Rubinstein, J. Plowman and M. R. Boyd, J. Natl. Cancer Inst., 1989, 81, 1088-1092. 